\title{
PENGARUH PELATIHAN DAN MOTIVASI TERHADAP KINERJA KARYAWAN DI PT BANK NEGARA INDONESIA (PERSERO) TBK KANTOR WILAYAH JAKARTA SENAYAN DENGAN METODE SURVEY EXPLANATIVE
}

\author{
Siti Nur Amanah \\ Politeknik STIA LAN Jakarta \\ Jl. Pejompongan Raya, Jakarta Pusat 10260 \\ E-mail : siti.amanah@bni.co.id
}

\begin{abstract}
ABSTRAK
Pengembangan SDM melalui pelatihan di Bank BNI ini merupakan bagian dari manajemen intern perusahaan. Sebagai bagian yang memberikan pengaruh besar pada perusahaan, hal ini pastinya tidak bisa dianggap sepele. Selain itu motivasi kerja merupakan salah satu faktor yang dapat memberikan pengaruh dalam meningkatkan kinerja karyawan. Tujuan dari penelitian ini adalah untuk meneliti adakah pengaruh pelatihan serta motivasi kerja terhadap kinerja karyawan di PT BNI Kantor Wilayah Jakarta Senayan, dengan menggunakan satu variabel terikat yaitu Kinerja Karyawan serta dua variabel bebas yaitu Pelatihan dan Motivasi Kerja. Hasil penelitian ini menunjukkan adanya pengaruh Pelatihan terhadap kinerja dengan koefisien regresi sebesar 1.345 dan adanya pengaruh motivasi kerja terhadap kinerja dengan koefisien regresi sebesar 1,238 serta menghasilkan kontribusi Pelatihan terhadap kinerja sebesar 43\%, dan kontribusi Motivasi Kerja terhadap kinerja sebesar 55,8\%. Sedangkan kontribusi Pelatihan dan Motivasi Kerja secara bersama-sama terhadap kinerja sebesar 62,8\%. Dari hasil penelitian dapat disimpulkan bahwa kontribusi Pelatihan memperoleh hasil terkecil dibandingkan dengan Motivasi, untuk itu disarankan perlunya perhatian terhadap Pelatihan Karyawan di PT BNI Kantor Wilayah Jakarta Senayan, salah satunya dengan meningkatkan kegiatan pelatihan hendaknya bisa terus dilaksanakan dengan adanya beberapa peningkatan, baik secara metode maupun materi Diktat serta pelaksanaannya diberikan secara continue disesuaikan dengan tingkat pekerjaan dan perkembangan ilmu pengetahuan dan teknologi.
\end{abstract}

Kata Kunci : Pengembangan SDM, Pelatihan, Motivasi Kerja dan Kinerja Karyawan

\section{PENDAHULUAN}

Pengembangan SDM melalui pelatihan di Bank BNI ini merupakan bagian dari manajemen intern perusahaan. Sebagai bagian yang memberikan pengaruh besar pada perusahaan, hal ini pastinya tidak bisa dianggap sepele. Itulah sebabnya, Bank BNI harus terus mempersiapkan generasi yang tangguh dan siap Bereksplorasi dengan segala kemampuan yang dimiliki. Kemampuan yang dimiliki setiap SDM harus terus dikembangkan hingga kemampuan tersebut mampu memberikan kontribusi yang besar untuk perusahaan.

Metode yang ditempuh perusahaan untuk meningkatkan kualitas SDM di Bank BNI adalah dengan menyusun strategi pengembangan-pengembangan SDM itu sendiri. Sebagai implikasi dari semakin meningkatnya tingkat persaingan, tuntutan sumber daya manusia yang berkualitas semakin meningkat pula. Sehingga perlu dilakukan upayaupaya peningkatan kualitas sumber daya manusia, yang antara lain dapat dilakukan dengan pelatihan.

Upaya yang dilakukan oleh BNI sejalan dengan penelitian yang dilakukan oleh Khan yang menyimpulkan bahwa pelatihan berkontribusi besar terhadap kinerja karyawan. Ada hubungan positif antara kinerja karyawan dengan pelatihan dan motivasi. Studi ini menunjukkan bahwa pelatihan dan motivasi memiliki impak positif pada kinerja karyawan ( Khan, 2012).
Pelatihan dan pengembangan adalah merupakan investasi organisasi yang penting dalam sumber daya manusia (Widodo, 2017). Pelatihan melibatkan segenap sumber daya manusia untuk mendapatkan pengetahuan dan keterampilan pembelajaran sehingga mereka segera akan dapat menggunakannya dalam pekerjaan.

Pelatihan dapat juga diartikan sebagai suatu proses memperbaiki keterampilan kerja karyawan untuk membantu pencapaian tujuan perusahaan (Bangun, 2017). Selanjutnya bahwa pelatihan secara singkat didefinisikan sebagai suatu kegiatan untuk meningkatkan kinerja saat ini dan kinerja di masa mendatang (Zainal, 2015).

Pelatihan dan pengembangan memiliki dampak positif pada pengetahuan umum, kualitas \& kuantitas kerja, keterampilan fungsional, dan motivasi \& kesetiaan mereka dan ini semua terkait dengan kinerja baik kuat atau sedang tetapi dalam arah yang mendukung (Vincent, 2020).

Ada beberapa dimensi dan indikator dalam pelatihan yaitu: 1) Instruktur yang dipengaruhi oleh pendidikan dan penguasaan materi. Pendidikan lebih diarahkan pada peningkatan kemampuan (ability) seseorang melalui jalur formal dengan jangka waktu yang panjang, guna memaksimalkan penyampaian materi kepada peserta pelatihan. Penguasaan materi bagi seorang instruktur merupakan hal yang penting untuk dapat melakukan proses pelatihan dengan baik sehingga para peserta pelatihan dapat memahami materi yang hendak disampaikan. 2) Peserta 
yang didukung oleh semangat mengikuti pelatihan dan proses seleksi yaitu pemilihan sekelompok orang yang paling memenuhi kriteria untuk posisi yang tersedia di perusahaan. 3) Materi, di mana suatu materi sebaiknya dapat menyesuaikan dengan tujuan yang ingin dicapai, komponen peserta pelatihan dan menetapkan sasaran yang akan dituju. Dan 4) Metode, yaitu dapat dilakukan dengan metode penyampaian sesuai dengan materi yang hendak disampaikan, sehingga diharapkan peserta pelatihan dapat menangkap maksud dan tujuan dari apa yang disampaikan oleh instruktur dan memiliki sasaran yang jelas agar lebih menjamin berlangsungnya kegiatan pelatihan sumber daya manusia yang efektif apabila memiliki sasaran yang jelas yaitu memperlihatkan pemahaman terhadap kebutuhan peserta pelatihan (Mangkunegara, 2011).

Dalam meningkatkan motivasi kerja para pegawainya maka BNI melakukannya dengan strategi melalui Reward dan Recognition. BNI memberikan remunerasi kepada seluruh pegawai untuk meningkatkan motivasi dan kinerja mereka. Kebijakan remunerasi didasari pada kompetensi, pengalaman dan kinerja pegawai.

Pengaruh motivasi terhadap kinerja karyawan bank komersial di Kenya: Sebuah studi kasus Bank Umum Kenya di Migori County yang menyimpulkan bahwa seorang manajer harus mengetahui bahwa karyawan termotivasi oleh imbalan uang. Disarankan bahwa ada kebutuhan bagi manajer untuk memiliki skema motivasi yang komprehensif di semua aspek organisasi karena ini berbanding lurus dengan output dari karyawan (Omollo, 2015).

Motivasi adalah kekuatan yang ada dalam seseorang, yang mendorong perilakunya untuk melakukan tindakan (Widodo, 2015). Motivasi berasal dari kata latin movere yang berarti dorongan, daya penggerak atau kekuatan yang menyebabkan sesuatu tindakan atau perbuatan (Suwanto \& Priansa, 2016). Kata movere dalam Bahasa Inggris sering memadankan dengan motivation yang berarti pemberian motif, penembusan motif, atau hal yang menimbulkan dorongan atau keadaan yang menimbulkan dorongan. Secara harfiah motivasi berarti pemberian motif.

Motivasi kerja sebagai kesediaan untuk melaksanakan upaya tinggi untuk mencapai tujuan-tujuan ke organisasi yang di kendalikan oleh kemampuan upaya untuk memenuhi kebutuhan individual tertentu (Robins, 2014).

Dimensi dan indikator motivasi adalah 1) Kebutuhan untuk berprestasi, 2) Kebutuhan memperluas pergaulan, dan 3) Kebutuhan untuk menguasai sesuatu pekerjaan (Wibowo, 2016).

Kinerja atau dalam istilah lain performance merupakan salah satu standar atau ukuran keberhasilan seseorang individu atau sekelompok pegawai untuk diakui oleh pimpinan dalam suatu perusahaan atau organisasi dan salah satu faktor penyebab tercapainya tujuan organisasi.

Kinerja adalah kemampuan pegawai dalam melakukan sesuatu keahlian tertentu (Sinambela, 2017). Hal lain pengertian dari kinerja itu berasal dari kata performance yang berarti hasil pekerjaan atau prestasi kerja (Wibowo, 2016). Kinerja merupakan singkatan dari kinetik energi kerja yang padanannya dalam Bahasa Inggris adalah performance (Kirana, 2017).

Namun Dalam penelitian ini yang dimaksud dengan kinerja adalah suatu gambaran mengenai tingkat pencapaian pelaksanaan suatu program dari pegawai Bank BNI Kantor Wilayah Jakarta Senayan dalam mewujudkan sasaran, tujuan, visi dan misi organisasi yang dituangkan melalui perencanaan strategis Bank BNI (Moeheriono \& Si, 2012). Adapun indikator untuk mengukur kinerja karyawan secara individu ada enam indikator, yaitu (Robins, 2014): 1) Kualitas kerja diukur dari persepsi karyawan terhadap kualitas pekerjaan yang dihasilkan serta kesempurnaan tugas terhadap keterampilan dan kemampuan karyawan. 2) Kuantitas merupakan jumlah yang dihasilkan dinyatakan dalam istilah seperti jumlah unit, jumlah siklus aktivitas yang diselesaikan. 3) Ketepatan waktu merupakan tingkat aktivitas diselesaikan pada awal waktu yang dinyatakan, dilihat dari ketepatan dan kecepatan dalam suatu pekerjaan. 4) Efektivitas merupakan tingkat penggunaan sumber daya organisasi (tenaga, uang, teknologi, bahan baku) dimaksimalkan dengan maksud menaikkan hasil dari setiap unit dalam penggunaan sumber daya. 5) Kemandirian merupakan tingkat seorang karyawan yang nantinya akan dapat menjalankan fungsi kerjanya Komitmen kerja. Merupakan suatu tingkat dimana karyawan mempunyai komitmen kerja dengan instansi dan tanggung jawab karyawan terhadap kantor.

\section{RUANG LINGKUP}

Pelatihan dan motivasi akan berpengaruh terhadap kinerja dari karyawan dalam suatu organisasi. Di mana pelatihan akan memberikan dampak adanya peningkatan kemampuan dari seorang pegawai sehingga pegawai dapat menyelesaikan pekerjaannya dengan hasil yang baik dan sesuai dengan standar yang diberikan oleh perusahaan. Seorang karyawan bisa saja mengembangkan diri di luar organisasi, namun hasil yang diperoleh pastinya tidak sejalan dengan tujuan, visi dan misi perusahaan. Sehingga pemberian pelatihan tentunya harus mendukung apa yang ingin dicapai oleh perusahaan sehingga dapat menunjang kinerja karyawan dan perusahaan. Pelatihan juga harus sesuai dengan bidang pekerjaan yang dibutuhkan dari suatu unit di mana dapat mendukung peningkatan kemampuan.

Bidang perbankan yang tentunya berkembang sesuai dengan kemajuan teknologi dan menyesuaikan dengan kebiasaan serta kebutuhan dari masyarakat, maka pelatihan yang diberikan oleh perusahaan juga harus memperhatikan hal tersebut sehingga perusahaan dapat menjaga kinerja dan mampu melayani nasabah dengan baik.

Sama halnya dengan penelitian maka motivasi kerja juga menjadi salah satu komponen penting dalam peningkatan kinerja karyawan di suatu organisasi. Motivasi yang diberikan dapat diberikan melalui kesempatan untuk berprestasi, kesempatan untuk memperluas pergaulan dan kesempatan untuk menguasai suatu pekerjaan. Dengan adanya motivasi maka akan mendukung semangat karyawan untuk menjadi yang terbaik dalam bidangnya. 
Hasil penelitian yang diharapkan dari beberapa permasalahan tersebut untuk mengetahui peningkatan kinerja karyawan setelah adanya pelatihan dan motivasi kerja yang diberikan oleh Bank BNI Kantor Wilayah Jakarta Senayan.

\section{BAHAN DAN METODE}

Penelitian ini dilakukan untuk pengkaji pengaruh antar variable Penelitian ini termasuk dalam penelitian asosiatif kausalitas. Penelitian asosiatif merupakan penelitian yang bertujuan untuk mengetahui hubungan antara dua variable atau lebih (Sugiyono, 2010b). Bentuk hubungan antara variable yang Akan diteliti adalah hubungan kausal yaitu hubungan sebab akibat (variable independen mempengaruhi variable dependen).

Dalam penelitian ini akan diuji apakah ada pengaruh yang signifikan antara kualitas program pelatihan, motivasi dan budaya organisasi terhadap kinerja karyawan pada Bank BNI Kantor Wilayah Jakarta Senayan. Metode penelitian yang digunakan adalah metode survey dan verifikasi adalah menguji kebenaran sesuatu dalam bidang yang telah ada (Sugiyono, 2014). Untuk menguji kebenaran tersebut digunakan perhitungan-perhitungan statistik untuk menguji hipotesis.

\subsection{Populasi, Sampel dan Teknik Sampling}

Dalam penelitian ini akan diuji apakah ada pengaruh yang signifikan antara pelatihan, motivasi kerja terhadap kinerja karyawan pada Bank BNI. Metode penelitian yang digunakan adalah metode survey dan verifikasi yaitu untuk menguji teori dengan pengujian hipotesis. Pengujian hipotesis dilakukan dengan menggunakan perhitungan statistik yang digunakan untuk menguji pengaruh variabel $\mathrm{X} 1$ dan X2 terhadap Y. Verifikasi berarti menguji teori dengan pengujian suatu hipotesis apakah diterima atau ditolak (Sugiyono, 2014).

Sampel adalah bagian dari jumlah dan karakteristik yang dimiliki oleh populasi tersebut (Sugiyono, 2010). Bila populasi besar, dan penelitian tidak mungkin mempelajari semua yang ada pada populasi, maka peneliti dapat menggunakan sampel yang diambil dari populasi itu.

Pada penelitian ini Teknik sampling yang digunakan adalah non probability sampling yaitu suatu teknik penarikan sampel yang digunakan dengan tidak memberi peluang atau kesempatan yang sama bagi setiap unsur atau anggota populasi untuk dipilih menjadi sampel. Dari jumlah populasi sebanyak 100 orang karyawan maka seluruh populasi tersebut akan diambil sebagai sampel dalam penelitian. Hal tersebut termasuk dalam sampel jenuh yang merupakan salah satu teknik sampling yang masuk ke dalam non probability sampling, yaitu suatu teknik penarikan sampel digunakan apabila keseluruhan anggota populasi digunakan sebagai sampel. Untuk menetapkan sampel adalah apabila jumlah sampel kurang dari 100 maka yang menjadi sampel adalah keseluruhan dari populasi yang ada (Sugiyono, 2010). Jumlah sampel yang diambil dapat dilihat melalui tabel 1 .
Tabel 1. Jumlah Sampel

\begin{tabular}{|c|c|c|}
\hline No & $\begin{array}{c}\text { Jenjang } \\
\text { Jabatan }\end{array}$ & Populasi \\
\hline 1 & MGR & $\mathbf{2 3}$ \\
\hline 2 & AMGR & 44 \\
\hline 3 & ASST & $\mathbf{3 3}$ \\
\hline Jumlah & & $\mathbf{1 0 0}$ \\
\hline
\end{tabular}

\subsection{Teknik Pengumpulan Data}

Dalam rangka memperoleh data atau informasi yang mendukung tujuan penelitian, penulis menggunakan teknik pengumpulan data sebagai berikut:

1. Teknik Pengumpulan Data Primer dalam penelitian ini menggunakan Kuesioner dan melakukan observasi atau pengamatan langsung pada objek penelitian.

2. Teknik Pengumpulan Data Sekunder teknik pengumpulan data yang dilakukan melalui studi dan bahan-bahan kepustakaan yang diperlukan untuk mendukung data primer yaitu dengan studi kepustakaan dan studi dokumenter.

\subsection{Teknik Pengolahan Data}

Pada jenis penelitian kuantitatif ini maka pengolahan data dilakukan setelah data terkumpul dengan tahapan sebagai berikut:

1. Penyuntingan Data (Editing) suatu kegiatan yang bertujuan untuk meneliti kembali apakah isian pada lembar kuesioner sudah cukup baik dan untuk mengetahui kemungkinan adanya kekeliruan, kesalahan ataupun ketidak sesuaian pada saat melakukan penelitian.

2. Pengkodean Data (Coding) yaitu mengklasifikasikan jawaban dari responden menurut kriteria tertentu serta dikelompokkan menurut variable dan indikatornya untuk memudahkan analisis selanjutnya.

3. Tabulasi Data (Tabulating) yaitu mengelompokkan data dalam bentuk table distribusi frekuensi untuk memudahkan identifikasi.

\subsection{Instrumen Penelitian}

Data yang diperlukan dalam penelitian ini pada dasarnya dapat dikelompokkan menjadi dua variable utama : variable Independen (X1 dan $\mathrm{X} 2)$ dan variable dependen (Y) yaitu sebagai berikut:

1. Pelatihan (X1) yaitu standar yang harus dipenuhi oleh organisasi atau industri produk dan jasa untuk memenuhi persyaratan sebagai salah satu usaha meningkatkan mutu sumber daya manusia dalam dunia kerja. Data ini diperoleh dari hasil survey (kuesioner) dan observasi.

2. Motivasi (X2) yaitu suatu keadaan psikologis yang muncul akibat dorongan untuk memenuhi kebutuhan individu. Data ini diperoleh dari hasil survei (kuesioner) dan observasi.

3. Kinerja Karyawan (Y) yaitu kesuksesan seseorang di dalam melaksanakan suatu pekerjaan. Data ini diperoleh dari hasil survey (kuesioner) dan observasi. 
Instrumen penelitian adalah suatu alat yang digunakan untuk mengukur fenomena alam maupun sosial yang diamati. Secara spesifik semua fenomena ini disebut variabel penelitian. (Sugiyono, 2010)

\section{PEMBAHASAN}

Pada sub bab ini akan dibahas hasil penelitian yang diperoleh setelah dilakukan rangkaian pengamatan yang dimulai dari pengamatan permasalahan, penyusunan instrument, penyebaran kuesioner, pengumpulan dan pengolahan data dengan menggunakan Software SPSS (Statistical Product and Service Solution).

\subsection{Gambaran Umum Lokasi Penelitian}

PT Bank Negara Indonesia (PERSERO) Tbk (selanjutnya disebut "BNI" atau "Bank") pada awalnya didirikan di Indonesia sebagai bank sentral dengan nama "Bank Negara Indonesia" berdasarkan Peraturan Pemerintah Pengganti Undang-Undang No. 2 tahun 1946 tanggal 5 Juli 1946. Selanjutnya, berdasarkan UndangUndang No. 17 tahun 1968, BNI ditetapkan menjadi "Bank Negara Indonesia 1946", dan statusnya menjadi Bank Umum Milik Negara. Selanjutnya, peran BNI sebagai bank yang diberi mandat untuk memperbaiki ekonomi rakyat dan berpartisipasi dalam pembangunan nasional dikukuhkan oleh UU No. 17 tahun 1968 tentang Bank Negara Indonesia 1946.

Kantor Wilayah yang selanjutnya disebut Kanwil adalah kantor Bank yang membantu kantor pusat Bank yang bersangkutan melakukan fungsi administrasi dan koordinasi terhadap beberapa kantor cabang di suatu wilayah tertentu. Saat ini terdapat sebanyak 14 Kantor Wilayah Bank BNI yang tersebar di seluruh Indonesia yang salah satunya adalah Kantor Wilayah Jakarta Senayan.

Gambaran umum dari pegawai Bank BNI Wilayah Jakarta Senayan dapat dilihat sebagaimana karakteristik responden yang didapatkan melalui pengisian kuesioner yang terdiri dari komponen jenis kelamin, usia, tingkat Pendidikan dan masa kerja.

Berdasarkan tabel 2 bahwa jenis kelamin responden menunjukkan, yaitu 59\% responden berjenis kelamin lakilaki atau sebanyak 59 orang sedangkan sisanya berjenis kelamin perempuan menunjukkan angka $41 \%$ atau sebanyak 41 responden dari total keseluruhan 100 responden.

Tabel 2. Tabel Frekuensi Jenis Kelamin Responden

\begin{tabular}{|cl|c|c|c|c|}
\hline & Frequency & Percent & Valid Percent & Cumulative Percent \\
\hline Valid & LAKI-LAKI & 59 & 59.0 & 59.0 & 59.0 \\
& PEREMPUAN & 41 & 41.0 & 41.0 & 100.0 \\
& Total & $\mathbf{1 0 0}$ & $\mathbf{1 0 0 . 0}$ & $\mathbf{1 0 0 . 0}$ & \\
\hline
\end{tabular}

Selanjutnya pada tabel 3 di mana statistika berdasarkan usia responden dapat diinformasikan data sebagai berikut:

1. Terdapat 17 responden atau sebesar $17 \%$ yang berusia $<30$ tahun

2. Terdapat 37 responden atau sebesar $37 \%$ yang berusia antara usia 31-35 tahun

3. Terdapat 21 responden atau sebesar $21 \%$ yang berusia antara 36-40 tahun

4. Terdapat 14 responden atau sebesar $14 \%$ yang berusia antara $41-45$ tahun

5. Terdapat 8 responden atau sebesar $8 \%$ yang berusia $46-50$ tahun

6. Dan hanya terdapat 3 responden atau sebesar $3 \%$ yang berusia $>50$ tahun.

Tabel 3. Tabel Frekuensi Usia Responden

\begin{tabular}{|c|c|c|c|c|c|}
\hline & Frequency & Percent & Valid Percent & Cumulative Percent \\
\hline Valid & $<30$ Tahun & 17 & 17.0 & 17.0 & 17.0 \\
\hline & 31-35 Tahun & 37 & 37.0 & 37.0 & 54.0 \\
\hline & 36-40 Tahun & 21 & 21.0 & 21.0 & 75.0 \\
\hline & 41-45 Tahun & 14 & 14.0 & 14.0 & 89.0 \\
\hline & 46-50 Tahun & 8 & 8.0 & 8.0 & 97.0 \\
\hline & $>50$ Tahun & 9 & 9.0 & 9.0 & 100.0 \\
\hline & Total & 100 & 100.0 & 100.0 & \\
\hline
\end{tabular}

Berdasarkan statistik masa kerja responden diperoleh informasi sebagaimana pada tabel 4 yaitu sebagai berikut:

1. Hanya ada 8 responden atau sebesar $8 \%$ yang memiliki masa kerja $<5$ tahun

2. Terdapat 55 responden atau sebesar $55 \%$ yang memiliki masa kerja antara 6-10 tahun

3. Terdapat 15 responden atau sebesar $15 \%$ yang memiliki masa kerja antara 11-15 tahun

4. Terdapat 15 responden atau sebesar $15 \%$ yang memiliki masa kerja antara 16-20 tahun

5. Dan terdapat 7 responden atau sebesar $7 \%$ yang memiliki masa kerja $>20$ tahun. 
Tabel 4. Tabel Frekuensi Masa Kerja Responden

\begin{tabular}{|cl|c|c|c|c|}
\hline & Frequency & Percent & Valid Percent & Cumulative Percent \\
\hline Valid & $<$ 5 Tahun & 8 & 8.0 & 8.0 & 8.0 \\
& 6-10 Tahun & 55 & 55.0 & 55.0 & 63.0 \\
11-15 Tahun & 15 & 15.0 & 15.0 & 78.0 \\
16-20 Tahun & 15 & 15.0 & 15.0 & 93.0 \\
>20 Tahun & 7 & 7.0 & 7.0 & 100.0 \\
& Total & $\mathbf{1 0 0}$ & $\mathbf{1 0 0 . 0}$ & $\mathbf{1 0 0 . 0}$ & \\
\hline
\end{tabular}

Berdasarkan tabel 5 mengenai pendidikan yang dimiliki responden diperoleh informasi sebagai berikut:

1. Tidak terdapat yang berpendidikan SLTP/sederajat

2. Terdapat 2 responden atau sebesar $2 \%$ yang berpendidikan SLTA/sederajat

3. Terdapat 11 responden atau sebesar $11 \%$ yang berpendidikan Diploma/D-III

4. Terdapat 66 responden atau sebesar $66 \%$ yang berpendidikan Sarjana/S-1

5. Dan terdapat 21 responden atau sebesar $21 \%$ yang berpendidikan Magister/S-2

6. Sedangkan tidak ada yang memiliki jenjang pendidikan Doktor/S-3.

Tabel 5. Tabel Frekuensi Pendidikan Responden

\begin{tabular}{|ll|c|c|c|c|}
\hline & Frequency & Percent & Valid Percent & $\begin{array}{c}\text { Cumulative } \\
\text { Percent }\end{array}$ \\
\hline Valid & SLTA/SEDERAJAT & 2 & 2.0 & 2.0 & 2.0 \\
& D-III & 11 & 11.0 & 11.0 & 13.0 \\
& S-1 & 66 & 66.0 & 66.0 & 79.0 \\
& S-2 & 21 & 21.0 & 21.0 & 100.0 \\
& Total & $\mathbf{1 0 0}$ & $\mathbf{1 0 0 . 0}$ & $\mathbf{1 0 0 . 0}$ & \\
\hline
\end{tabular}

\subsection{Pengujian Hipotesis Penelitian}

Pengujian hipotesis berdasarkan Kerangka Pemikiran Teoretis dalam penelitian ini bertujuan untuk menguji tiga hipotesis yang dirumuskan sebagai berikut dan tergambar pada gambar 1 yaitu:

1. Pelatihan (X1) berpengaruh positif/signifikan terhadap Kinerja Karyawan (Y)

2. Motivasi (X2) berpengaruh positif/signifikan terhadap Kinerja Karyawan (Y)

3. Pelatihan (X1) dan Motivasi (X2) berpengaruh positif/signifikan terhadap Kinerja Karyawan (Y)

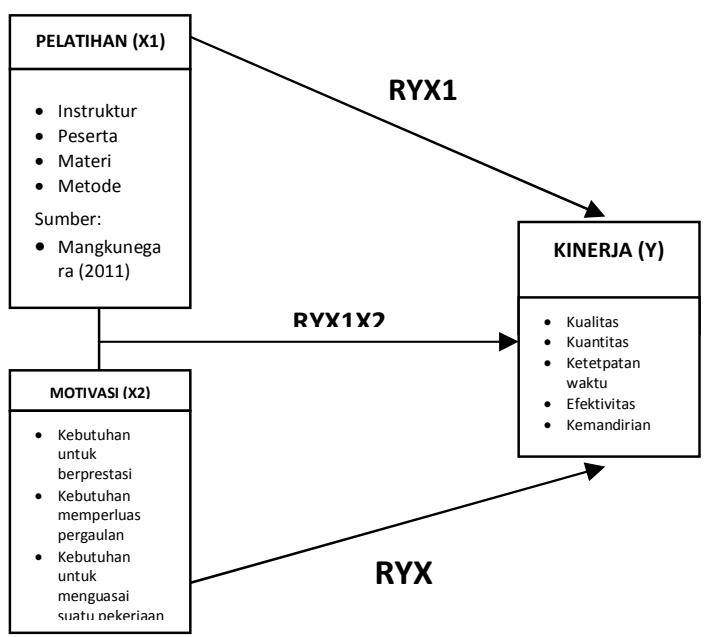

Gambar 1. Model Penelitian

\subsection{Pengujian Korelasi Sederhana Antar Variabel}

Pengujian korelasi merupakan derajat ke eratkan hubungan antara variable yang dinyatakan dengan koefisien korelasi di mana hubungan antara variable independen $(\mathrm{X})$ dan variable $(\mathrm{Y})$ bersifat positif jika variable jika variable independen $(\mathrm{X})$ naik dan variabel dependen (Y) juga naik. Namun bersifat negative jika variabel independen $(\mathrm{X})$ turun dan variabel dependen $(\mathrm{Y})$ turun. Derajat hubungan yang dinyatakan dengan $r$ disebut dengan koefisien korelasi sampel yang merupakan penduga bagi koefisien populasi yang bernilai paling kecil -1 dan paling besar 1 .

Dari data tabel 6 diketahui antara variabel Pelatihan (X1) dan variabel Kinerja (Y) menghasilkan korelasi yang signifikan dengan nilai korelasi nya sebesar 0,656 yang berarti terdapat korelasi yang kuat antara Pelatihan (X1) dengan Kinerja (Y)

Begitu juga diketahui antara variabel Motivasi (X2) dan variabel Kinerja (Y) menghasilkan korelasi yang signifikan dengan nilai korelasi nya sebesar 0,747 yang berarti terdapat korelasi yang kuat antara Motivasi (X2) dengan Kinerja (Y) di PT BNI Kantor Wilayah Jakarta Senayan. 
Tabel 6. Hasil Uji Korelasi Antar Variabel

\begin{tabular}{|cl|r|r|r|}
\hline & & PELATIHAN & MOTIVASI & KINERJA \\
\hline PELATIHAN & Pearson Correlation & 1 & $.572^{* *}$ & $.656^{* *}$ \\
& Sig. (2-tailed) & 100 & .000 & .000 \\
& N & $.572^{* *}$ & 100 & 100 \\
\hline MOTIVASI & Pearson Correlation & .000 & 1 & $.747 *$ \\
& Sig. (2-tailed) & 100 & 100 & .000 \\
& N & & 100 \\
& & $.656^{* *}$ & .747 & 1 \\
KINERJA & Pearson & .000 & .000 & 100 \\
& Correlation & 100 & .747 & 100 \\
& Sig. (2-tailed) & $.656^{* *}$ & & 1 \\
\hline
\end{tabular}

\subsection{Pengujian Regresi Liner antar Variabel}

Analis regresi linier sederhana digunakan untuk mengukur besarnya pengaruh suatu variabel independen (X) terhadap variabel dependen (Y). dengan syarat jumlah sampel harus sama, jumlah variabel independen (X) adalah 1, nilai residual terdistribusi normal, terdapat hubungan linear antar variabel $(\mathrm{X})$ dan variabel $(\mathrm{Y})$, tidak terjadi adanya gejala hubungan heteroskedastisitas dan tidak terjadi adanya gejala multi korelasi. Berikut merupakan hasil uji Regresi Linier Sederhana dari masing-masing variable independen terhadap variabel dependen.

1. Pengaruh Pelatihan (X1) terhadap Kinerja Karyawan (Y)

Hipotesis pertama yang akan diuji adalah terdapat pengaruh Pelatihan (X1) terhadap Kinerja Karyawan (Y) pada PT BNI Kantor Wilayah Jakarta Senayan. Hasil perhitungan Regresi Linier Sederhana dapat dilihat pada Tabel berikut:

Berdasarkan tabel 7 bahwa hasil nilai koefisien regresi bernilai plus $(+)$ maka dapat dikatakan bahwa Pelatihan (X1) berpengaruh positif $(+)$ terhadap Kinerja Karyawan (Y) di PT BNI Kantor Wilayah Jakarta Senayan dan menghasilkan persamaan regresi $\mathrm{Y}=25,391+1,345 \mathrm{X}$, yang artinya Pelatihan berpengaruh positif dan signifikan terhadap kinerja karyawan.

Tabel 7. Hasil Uji Regresi Pelatihan terhadap Kinerja

Coefficients ${ }^{\text {a }}$

\begin{tabular}{|c|c|r|r|r|c|c|}
\hline \multirow{3}{*}{ Model } & \multicolumn{3}{|c|}{ Unstandardized Coefficients } & Standardized Coefficients & & \multirow{2}{*}{ Sig. } \\
\cline { 2 - 7 } & \multicolumn{2}{|c|}{ B } & Std. Error & Beta & & t \\
& (Constant) & 25.391 & 3.753 & & 6.766 & .000 \\
& PELATIHAN & 1.345 & .156 & .656 & 8.500 & .000 \\
\hline
\end{tabular}

a. Dependent Variable : KINERJA

Berdasarkan hasil uji regresi linear Pelatihan terhadap Kinerja diperoleh nilai $R$ Square sebesar 0,430 yang artinya bahwa pengaruh Pelatihan (X1) terhadap Kinerja Karyawan (Y) di PT BNI Kantor Wilayah Jakarta Senayan sebesar 43\%. Maka dapat disimpulkan bahwa "Pelatihan (X1) berpengaruh positif terhadap Kinerja Karyawan (Y) dengan total pengaruh sebesar 43\%". Dengan demikian, semakin tingginya tingkat Pelatihan yang diikuti seorang Karyawan di PT BNI Kantor Wilayah Jakarta Senayan maka berpengaruh terhadap peningkatan kinerja karyawan tersebut.

2. Pengaruh Motivasi (X2) terhadap Kinerja Karyawan (Y)

Hipotesis kedua yang akan diuji adalah terdapat pengaruh Motivasi (X2) terhadap kinerja Karyawan (Y) pada PT BNI Kantor Wilayah Jakarta Senayan. Hasil perhitungan Regresi Linier Sederhana dapat dilihat pada Tabel berikut:

Berdasarkan tabel 9 bahwa hasil nilai koefisien regresi bernilai plus (+) maka dapat dikatakan bahwa Motivasi (X2) berpengaruh positif (+) terhadap Kinerja Karyawan (Y) di PT BNI Kantor Wilayah Jakarta Senayan dan menghasilkan persamaan regresi $\mathrm{Y}=14,702+1,238 \mathrm{X}$. yang artinya Motivasi berpengaruh positif dan signifikan terhadap kinerja karyawan. 
Tabel 8. Hasil Uji Regresi Motivasi terhadap Kinerja

\begin{tabular}{|c|c|c|c|c|c|c|}
\hline \multirow[b]{3}{*}{ Model } & \multicolumn{3}{|c|}{ Coefficients $^{\text {a }}$} & \multirow[b]{2}{*}{ Standardized Coefficients } & \multirow[b]{3}{*}{$\mathbf{t}$} & \multirow[b]{3}{*}{ Sig. } \\
\hline & \multicolumn{3}{|c|}{ Unstandardized Coefficients } & & & \\
\hline & \multicolumn{2}{|l|}{$\mathbf{B}$} & Std. Error & Beta & & \\
\hline & (Constant) & 14.702 & 3.863 & & 3.806 & .000 \\
\hline & MOTIVASI & 1.238 & .111 & .747 & 11.121 & .000 \\
\hline
\end{tabular}

b. Dependent Variable : KINERJA

Berdasarkan hasil uji regresi linear Motivasi terhadap Kinerja diperoleh nilai R Square sebesar 0,558 yang artinya bahwa pengaruh Motivasi (X2) terhadap Kinerja Karyawan (Y) di PT BNI Kantor Wilayah Jakarta Senayan sebesar 55,8\%. Maka dapat disimpulkan bahwa "Motivasi (X2) berpengaruh positif terhadap Kinerja Karyawan (Y) dengan total pengaruh sebesar 55,8\%". Dengan demikian, semakin tingginya Motivasi seorang Karyawan di PT BNI Kantor Wilayah Jakarta Senayan maka berpengaruh terhadap peningkatan kinerja Karyawan tersebut.

3. Pengaruh Pelatihan (X1) dan Motivasi (X2) terhadap Kinerja Karyawan (Y)

Hipotesis ketiga yang akan diuji adalah terdapat pengaruh secara bersama-sama antara Pelatihan (X1) dan Motivasi (X2) terhadap kinerja Karyawan (Y) pada PT BNI Kantor Wilayah Jakarta Senayan. Hasil perhitungan Regresi Linier berganda dapat dilihat pada Tabel berikut:

Dari tabel 11 diperoleh nilai koefisien regresi bernilai plus (+) maka dapat dikatakan bahwa Pelatihan (X1) dan Motivasi (X2) berpengaruh positif (+) terhadap Kinerja Karyawan (Y) di PT BNI Kantor Wilayah Jakarta Senayan dan menghasilkan persamaan regresi $\mathrm{Y}=9,226+0,697 \mathrm{X} 1+0,916 \mathrm{X} 2$. Dalam penelitian ini nilainya adalah 9,226 yang merupakan angka konstan yang mempunyai arti bahwa jika tidak ada Pelatihan (X1) dan Motivasi (X2) maka nilai konsisten Kinerja Karyawan (Y) pada PT BNI Kantor Wilayah Jakarta Senayan adalah sebesar 9,226. Berikutnya b yaitu angka koefisien regresi yaitu nilainya adalah 0,697 dan 0,916 maka artinya Pelatihan (X1) dan Motivasi (X2) berpengaruh positif signifikan sebesar $69,7 \%$ dan $91,6 \%$.

Tabel 9. Hasil Uji Regresi Berganda Pelatihan dan Motivasi terhadap Kinerja

\begin{tabular}{|c|c|c|c|c|c|}
\hline \multirow[b]{3}{*}{ Model } & \multicolumn{3}{|c|}{ Coefficients ${ }^{\text {a }}$} & \multirow[b]{3}{*}{ t } & \multirow[b]{3}{*}{ Sig. } \\
\hline & \multicolumn{2}{|c|}{$\begin{array}{l}\text { Unstandardized } \\
\text { Coefficients }\end{array}$} & \multirow{2}{*}{$\begin{array}{c}\begin{array}{c}\text { Standardized } \\
\text { Coefficients }\end{array} \\
\text { Beta }\end{array}$} & & \\
\hline & B & $\begin{array}{l}\text { Std. } \\
\text { Error }\end{array}$ & & & \\
\hline (Constant) & 9.226 & 3.725 & & 2.477 & .015 \\
\hline PELATIHAN & 697 & .153 & .340 & 4.547 & .000 \\
\hline MOTIVASI & .916 & .124 & .553 & 7.395 & .000 \\
\hline
\end{tabular}

a. Dependent Variable : KINERJA

Berdasarkan hasil regresi linear berganda Pelatihan dan Motivasi terhadap Kinerja diperoleh nilai Adjusted $R$ Square sebesar 0,628 yang artinya bahwa pengaruh Pelatihan (X1) dan Motivasi (X2) terhadap Kinerja Karyawan (Y) di PT BNI Kantor Wilayah Jakarta Senayan sebesar $62,8 \%$. Maka dapat disimpulkan bahwa "Pelatihan (X1) dan Motivasi (X2) berpengaruh positif terhadap Kinerja Karyawan (Y)". Dengan demikian, semakin banyaknya tingkat Pelatihan dan dengan tingginya Motivasi seorang karyawan di PT BNI Kantor Wilayah Jakarta Senayan maka berpengaruh terhadap peningkatan kinerja Karyawan tersebut.

Sebagaimana dari rangkaian analis tersebut maka dapat dijelaskan, pertama ada variable Pengaruh Pelatihan (X1) terhadap Kinerja Karyawan (Y) menunjukkan bahwa Pelatihan memiliki hubungan serta berpengaruh dan signifikan terhadap kinerja pegawai dengan nilai koefisien korelasi sebesar 0,656 serta nilai koefisien regresi sebesar 1,345 atau 43\%, dengan demikian hipotesis penelitian terbukti. Kedua, pada variable Pengaruh Motivasi (X2) terhadap Kinerja Karyawan (Y) menunjukkan bahwa
Motivasi memiliki hubungan serta berpengaruh dan signifikan terhadap kinerja pegawai dengan nilai koefisien korelasi sebesar 0,747 serta nilai koefisien regresi sebesar 1,238 atau $55,8 \%$, dengan demikian hipotesis penelitian terbukti. Motivasi memiliki pengaruh yang positif dan signifikan terhadap tinggi rendahnya kinerja karyawan di PT BNI Kantor Wilayah Jakarta Senayan. Ketiga, pada variabel Pengaruh Pelatihan (X1) dan Motivasi (X2) terhadap Kinerja Karyawan (Y) secara simultan hasil penelitian ini menunjukkan bahwa Pelatihan dan Motivasi memiliki hubungan serta berpengaruh dan signifikan dengan nilai koefisien korelasi sebesar 0,797, koefisien regresi sebesar regresi sebesar 0,697 dan 0,916 atau sebesar $69,7 \%$ dan $91,6 \%$ serta hasil yang ditunjukkan oleh uji $\mathrm{F}$ menyatakan bahwa signifikan $\mathrm{F}_{\text {hitung }}$ sebesar 0,000 dimana $<$ dari $\mathrm{F}_{\text {tabel }} 0,05$ sehingga variabel independen berpengaruh secara signifikan terhadap variabel dependen, dengan demikian hipotesis penelitian terbukti. 


\section{KESIMPULAN}

Hasil korelasi menunjukkan angka 0,656 yang berarti bahwa terdapat respond yang kuat dan nilai koefisien regresi sebesar 1,345 sehingga dikarenakan nilai koefisien regresi bernilai plus $(+)$ maka dapat dikatakan bahwa Pelatihan (X1) berpengaruh positif $(+)$ terhadap Kinerja Karyawan (Y) di PT BNI Kantor Wilayah Jakarta Senayan. Dengan adanya pelatihan maka akan sangat membantu dalam pengembangan pegawai untuk meningkatkan kemampuan kerja dan pengetahuan, pegawai mampu menyelesaikan pekerjaannya dengan kualitas yang baik dan akurat sehingga tujuan perusahaan dapat tercapai.

Hasil korelasi menunjukkan angka 0,747 yang berarti bahwa terdapat respond yang kuat dan nilai koefisien regresi sebesar 1.238 sehingga dikarenakan nilai koefisien regresi bernilai plus $(+)$ maka dapat dikatakan bahwa Motivasi (X2) berpengaruh positif $(+)$ terhadap Kinerja Karyawan (Y) di PT BNI Kantor Wilayah Jakarta Senayan. Motivasi kerja dapat memacu keinginan pegawai untuk menjadi yang terbaik dalam bidangnya sehingga pegawai dapat memberikan kontribusi nya dalam membantu pencapaian tujuan perusahaan.

Hasil korelasi menunjukkan angka 0,797 dan dengan adanya kontribusi secara simultan variabel Pelatihan (X1) dan Motivasi (X2) terhadap Kinerja (Y) sebesar 62,8\% menghasilkan nilai koefisien regresi sebesar 0,697 dan 0,9611. Dikarenakan nilai koefisien regresi bernilai plus $(+)$ maka dapat dikatakan bahwa Pelatihan (X1) dan Motivasi (X2) berpengaruh positif $(+)$ terhadap Kinerja Karyawan (Y) di PT BNI Kantor Wilayah Jakarta Senayan. Jika kedua variable dilaksanakan dengan baik oleh perusahaan maka kinerja perusahaan akan meningkat seiring dengan pencapaian tujuan perusahaan.

\section{SARAN}

Dalam kaitannya dengan Pelatihan, perlu adanya perubahan sikap yang harus dilakukan oleh PT BNI Kantor Wilayah Jakarta Senayan yaitu dengan memberikan peluang untuk mengembangkan kemampuan dengan cara memberikan sosialisasi pelatihan yang akan diselenggarakan setiap tahunnya, memberikan kesempatan dan waktu kepada karyawan untuk mengikuti pelatihan dalam kurun waktu 1 atau 2 tahun sekali.

Dalam kaitannya dengan Motivasi, perlu adanya peningkatan motivasi yang harus dilakukan oleh PT BNI Kantor Wilayah Jakarta Senayan yaitu diantaranya, menciptakan lingkungan kerja yang lebih kondusif agar karyawan merasa lebih nyaman, memberikan fasilitas yang mendukung pekerjaan Perencanaan karier karyawan, memperbaiki sistem remunerasi.

Dalam kaitannya dengan Kinerja yang diperlukan untuk meningkatkan kinerja di PT BNI Kantor Wilayah Jakarta Senayan, yaitu melakukan intervensi guna perbaikan kinerja, berupa pelatihan, reorganisasi, penetapan sasaran agar kualitas hasil kerja karyawan lebih memuaskan, karyawan diharapkan lebih kreatif dan inovatif dalam melakukan pekerjaannya, kinerja karyawan jika dilihat dari kemampuan para karyawannya masih kurang, latar belakang pendidikan dan pengalaman sebagian karyawan masih rendah. Oleh karena itu pengembangan karier karyawan harus terus ditingkatkan dengan cara mengikuti pelatihan dan baik formal maupun informal.

\section{DAFTAR PUSTAKA}

Bangun, W. (2017). Manajemen Sumber Daya Manusia. In Jakarta: Erlangga.

Mangkunegara. (2011). Manajemen Sumber Daya Perusahaan. In Bandung: PT Refika Aditama.

Moeheriono, E., \& Si, D. M. 2012. Pengukuran Kinerja Berbasis Kompetensi. In Jakarta: Raja Grafindo Persada.

Khan, M. 2012. The Impact of Training and Motivation of Performance of Employees. Business Review, 7(2).

Omollo, P. A., \& Oloko, M. A. 2015. Effect of motivation on employee performance of commercial banks in Kenya: A case study of Kenya Commercial Bank in Migori County. International journal of human resource studies, 5(2), 87-103.

Kirana, K. C., \& Ratnasari, R. T. 2017. Evaluasi Kinerja Sumber Daya Manusia (SDM). In Yogyakarta: Gosyen Publishing.

Robins, stephen. p. 2014. Teori Budaya Organisasi. In Jakarta: Gramedia.

Sinambela, L. P. 2017. Manajemen Sumber Daya Manusia:Membangun Tim Kerja yang Solid untuk Meningkatkan Kinerja. Jurnal Populis, 2(4), 579596.

Sugiyono. 2010a. Metode Penelitian Administrasi. Bandung: Alfabeta.

Sugiyono. 2010b. Metodologi Penelitian pendidikan pendekatan kuantitatifa, kualitatif dan R\&D. Universitas Pendidikan Indonesia.

Sugiyono. 2014. Metode dan Prosedur Penelitian. EJournal.

Suwanto, \& Priansa, D. J. 2016. Manajemen SDM dalam Organisasi Publik dan Bisnis.pdf. In Bandung: Alfabeta.

Vincent, M. 2020. Impact of Training and Development on Employee Job Performance in Nigeria. Saudi Journal of Humanities and Social Sciences, 05(05), 265-268. https://doi.org/10.36348/sjhss.2020.v05i05.004

Wibowo. 2016. Manajemen Kinerja. Jakarta: Raja Grafindo Persada.

Widodo, S. E. 2015. Manajemen Sumber Daya Manusia. Yogyakarta: Pustaka Pelajar.

Widodo, S. E. 2017. Manajemen Pelatihan. Jakarta: Jaya Media.

Zainal, V. R. 2015. Manajemen Sumber Daya Manusia. Jakarta: Raja Grafindo Persada. 